\title{
Natural Resources Volatility and Economic Growth: Evidence from the Resource-Rich Region
}

\author{
Arshad Hayat ${ }^{1, *}$ and Muhammad Tahir ${ }^{2}$ \\ 1 Department of International Business, Metropolitan University Prague, 10031 Prague, Czech Republic \\ 2 Department of Management Sciences, COMSATS University Islamabad, Abbottabad Campus, \\ Abbottabad 22060, Pakistan; tahirm@cuiatd.edu.pk \\ * Correspondence: arshad.hayat@mup.cz
}

Citation: Hayat, Arshad, and Muhammad Tahir. 2021. Natural Resources Volatility and Economic Growth: Evidence from the ResourceRich Region. Journal of Risk and Financial Management 14: 84. https://doi.org/10.3390/jrfm14020084

Academic Editor: Thanasis Stengos

Received: 3 November 2020

Accepted: 13 February 2021

Published: 19 February 2021

Publisher's Note: MDPI stays neutral with regard to jurisdictional claims in published maps and institutional affiliations.

Copyright: (c) 2021 by the authors. Licensee MDPI, Basel, Switzerland. This article is an open access article distributed under the terms and conditions of the Creative Commons Attribution (CC BY) license (https:// creativecommons.org/licenses/by/ $4.0 /)$.

\begin{abstract}
This research paper investigates the impact of natural resources volatility on economic growth. The paper focused on three resource-rich economies, namely, UAE, Saudi Arabia, and Oman. Using data from 1970 to 2016 and employing the autoregressive distributed lag (ARDL) cointegration approach, we found that both natural resources and their volatility matter from the perspective of growth. The study found strong evidence in favor of a positive and statistically significant relationship between natural resources and economic growth for the economies of UAE and Saudi Arabia. Similarly, for the economy of Oman, a positive but insignificant relationship is observed between natural resources and economic growth. However, we found that the volatility of natural resources has a statistically significant negative impact on the economic growth of all three economies. This study contradicts the traditional concept of the resources curse and provides evidence of the resources curse in the form of a negative impact of volatility on economic growth.
\end{abstract}

Keywords: natural resources; volatility; economic growth; ARDL modeling; GCC

\section{Introduction}

Looking at the UN human development report (2015), we can see that major oil and gas producing nations like Norway, Australia, and Canada are at the top of the list, while other major natural resources producing countries like Argentina, Brunei, Saudi Arabia, Qatar, UAE, and Kuwait also reached a very high ranking in the UN human development report. However, there are other resource-rich countries that remain at the bottom of the ranking, e.g., Chad, Angola, Nigeria, Yemen, etc.

The impact of natural resource abundance on the economic performance of countries has been widely discussed in the research literature. Studies like Gelb (1988); Auty (1990); Sachs and Warner $(1995,2001)$, and Gylfason (2001) concluded that natural resource abundant countries tend to grow slower compared to resource scarce countries. This phenomenon was named the natural resource curse.

However, the debate on the natural resource curse is far from over, and many studies found that the presence of a natural resource curse is dependent on contingent factors. For instance, in a cross-country study of the natural resource curse, Iimi (2007) found that the quality of governance determines the negative effect of the natural resource curse on the economic growth of the country. Manzano and Rigobon (2001) found that the natural resource curse is dependent on debt overhang and the generally omitted factors that are correlated with the primary exports, and they conclude that the natural resource curse disappeared once they controlled for these two factors. However, in a later study, Sachs and Warner (2001) reaffirmed their earlier natural resource curse findings, controlling for endogeneity and omitting geographical and climate variables.

Gylfason and Gylfi (2006) found that when the share of natural resources in the output rises, demand for capital decreases in the economy, and that results in growth. The study further notes that improving the quality of institutions can remedy the capital market 
imperfections arising from natural resource and can mitigate the natural resource curse. Sala-i-Martin and Subramanian (2003) concluded that the natural resource abundance in Nigeria lowers the quality of institutions in Nigeria and that in turn causes poor economic growth. They suggest institutional quality improvements and redistribution of wealth to the public would mitigate the presence of the natural resource curse.

In this paper, we attempt to revisit the phenomenon of the natural resource curse in the 03-member countries of the Gulf Cooperation Council (GCC), namely, the United Arab Emirates, Saudi Arabia, and Oman. These countries are very resource-rich and are relatively stable, have similar institutions and governance, language and culture, and history and geography. The aforementioned similar characteristics are the indication that the selected countries are homogeneous. Consequently, the comparison and generalization of results will be meaningful, which is desirable from a policy perspective.

The paper contributes to the literature in three ways. Firstly, there is still no consensus about the direction of a relationship between natural resources and economic growth, as evident from previous studies. Hence, fresh evidence about the relationship between natural resources and economic growth was indeed needed as previous literature is largely inconclusive due to mixed findings. Secondly, many previous studies, when cross country analysis, start with the assumption of a monotonic relationship between resources and growth across countries. In such studies, the generalization of results becomes difficult as all economies are quite different from each other in terms of economic characteristics. Therefore, we conducted time series analysis for each country. Thirdly, in this paper, we model natural resource volatility in prices and quantity and investigate the impact of resource volatility on economic growth in the three GCC countries. We further explore the spillover effect of the resource volatility across the three GCC countries. The spillover effects of the volatility of natural resources is indeed an interesting but unexplored area in the empirical literature. Therefore, the current study is more comprehensive as compared to previous studies and hence would add to the literature substantially. We expected that the current study would attract the attention of policymakers and potential researchers.

The rest of the paper is organized as follows: Relevant literature is briefly discussed in the next section, while section three describes the data and discusses descriptive statistics. The fourth section presents the model, data, and estimating methodology. The penultimate section of the paper discusses the main results, while the final section concludes the paper.

\section{Literature Review}

The growing importance of natural resources from the perspective of economic growth has attracted the attention of both researchers and policymakers during the last couple of decades. Natural resources have contributed significantly to the growth performance of many countries over the years. For example, Paltseva and Jesper (2011) demonstrated that natural resources had contributed significantly to the economies of Norway, Australia, and Botswana. Similarly, the recent empirical literature is also optimistic about the positive impact of natural resources on economic growth. The recent study by Erum and Shahzad (2019) found that natural resources have contributed to the economic growth of economies with higher ICT diffusion. Interestingly, the same study also showed that the relationship between natural resources and economic growth is negative for economies with low ICT diffusion. Cavalcanti et al. (2011) challenged the view of the resource curse and provided evidence of the positive impact of natural resources on both income level and economic growth.

However, it is not necessary that natural resources would always positively impact economic growth. The positive role of natural resources in the growth process may be dependent on several other factors. For example, Raggl (2017) claimed that the positive linkages between natural resources and economic growth are dependent on quality institutions and control over corruption. Institutional quality must be improved in order to improve economic growth (Asiedu 2014) but also grab the full benefits of natural resources. Zallé (2019) also suggested African economies control corruption and investment 
in human capital in order to turn the resource curse into a resource blessing. Therefore, in the presence of weak institutions, poor human capital, and a high level of corruption, the relationship between natural resources and economic growth may turn negative. Also, there is ample empirical evidence about the adverse impacts of natural resources on the economic growth of the host countries. For example, Sachs and Warner (2001) highlighted that many resource-rich countries such as those located in Gulf and Latin America have not been able to achieve sustainable growth. This implies that the presence of natural resources may not be sufficient for better economic performance. Moreover, Gylfason and Gylfi (2006) pointed out that economic growth and prosperity do not depend on the presence of natural resources, although they are the main source of wealth of countries.

Asiedu and Lien (2011) investigated the impact of natural resources on the DemocracyFDI relationship for 112 countries during the period 1982-2007. Using both systems and differenced GMM, they demonstrated that the size of natural resources instead of its type could alter the relationship between democracy and FDI inflows. Asiedu (2006) have focused on African economies and commented based on results that natural resources can promote the FDI inflows. This implies that natural resources can promote the host countries' growth process through the channel of FDI. FDI inflows can enhance growth performance, as evident from previous literature. For example, the study of Ibhagui (2020) indicated that FDI could improve economic growth in Africa when the growth of population and human capital is above the threshold. Moreover, Ibhagui (2020) pointed out that the positive impact of FDI on economic growth is dependent on some other supportive factors.

Specifically, for the middle east region, the impact of natural resources, especially oil, on economic growth is also vastly researched. Birdsall and Arvind (2004) found that the countries have largely escaped the natural resource curse. However, other studies do point towards a relatively slow growth in the resource-rich middle eastern countries (see Auty (2004); Aoun (2009); Arezki and Nabli (2012); and Ben Ali et al. (2016)). However, most of these studies are cross country studies and considered natural resource quantity rather than resource volatility. In cross country studies, one of the problems that arises is the assumption of a monotonic relationship between resources and growth across countries. We carry out a time-series study for the three GCC countries that use volatility in natural resources and prices of natural resources and investigate its impact on economic growth. The remaining three countries of GCC (Bahrain, Kuwait, and Qatar) are ignored owing to their unavailability of data.

Finally, we have not considered institutional factors in our analysis. We have looked at the institutional quality of these countries and the institutional quality outlook of these countries is very similar. Therefore, we have ignored institutional factors in our analysis. In Figures 1-3, we have presented a graphical presentation of three institutional quality indicators (ICRG indicators) of the selected countries.

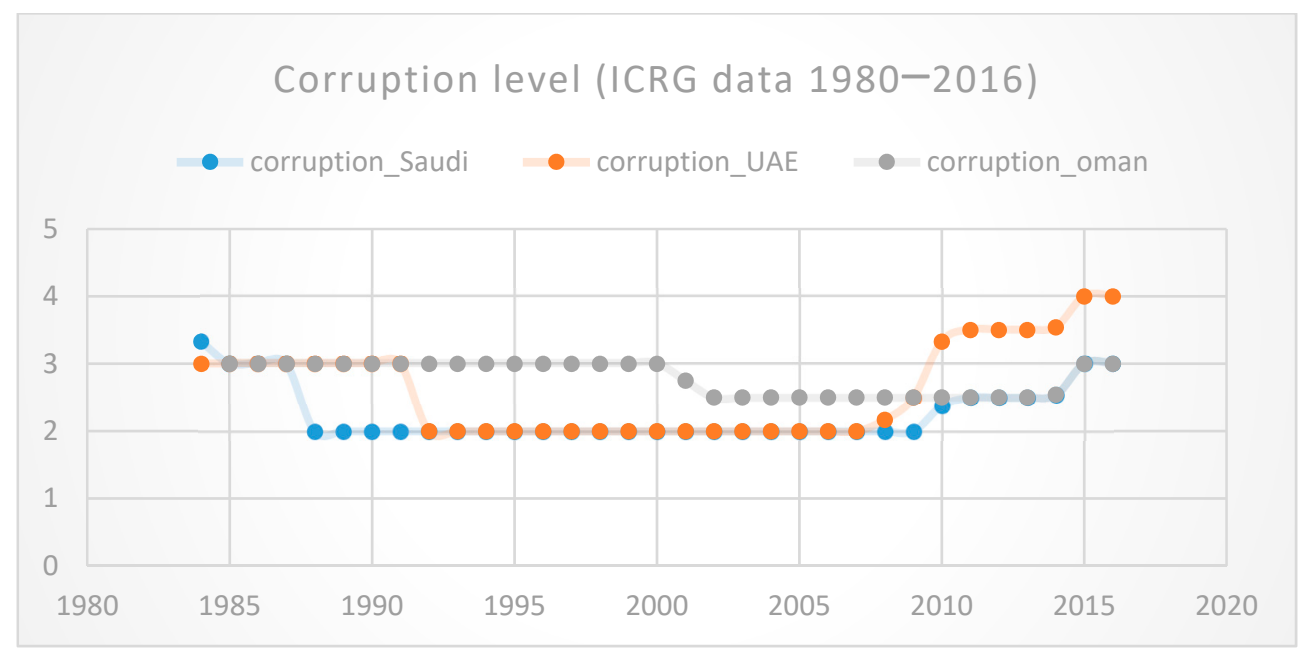

Figure 1. Corruption Level. 


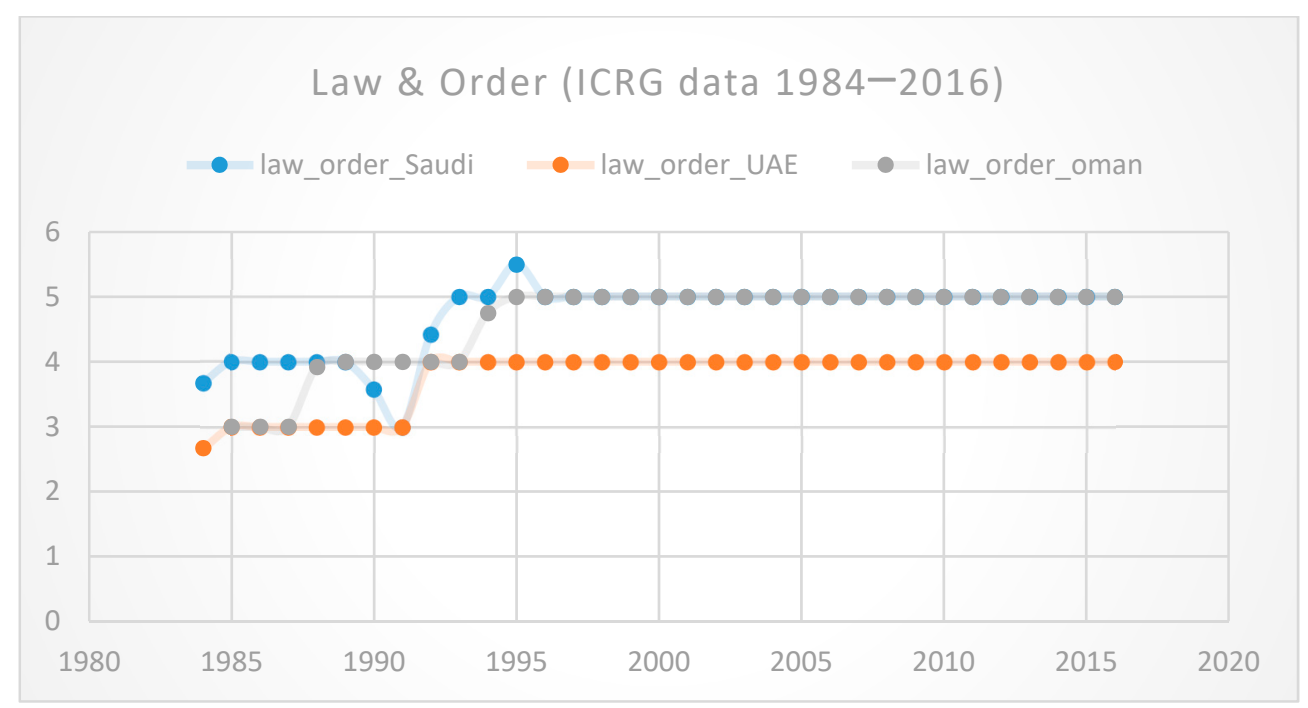

Figure 2. Law and Order.

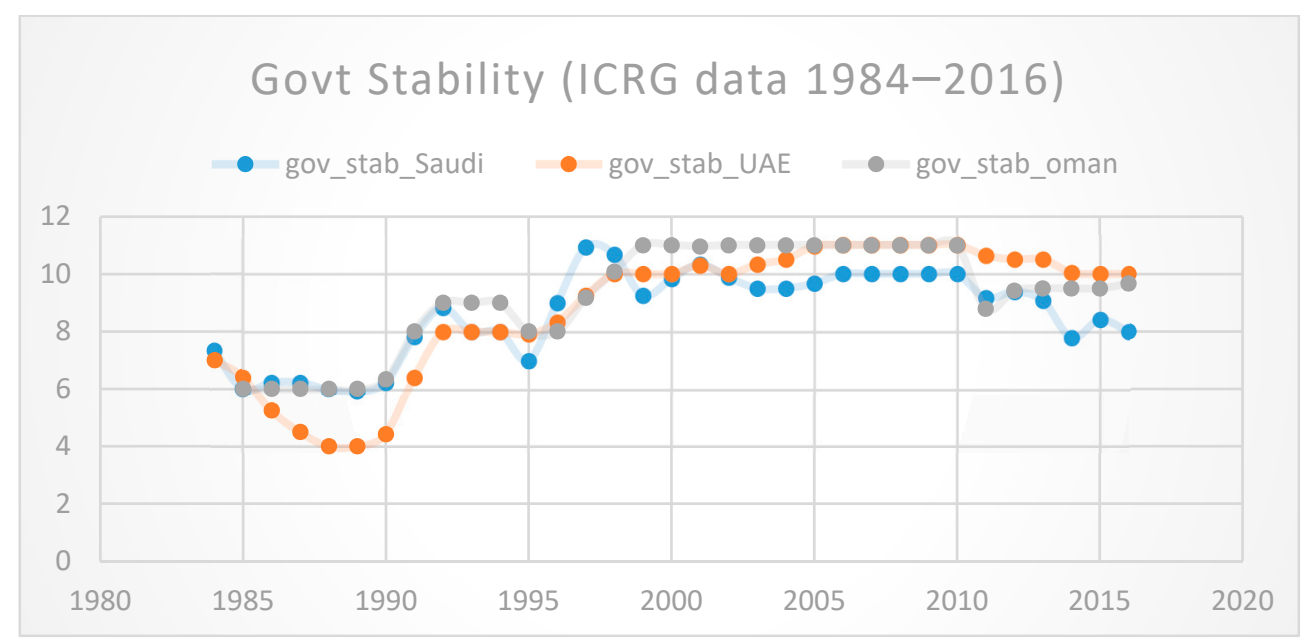

Figure 3. Government Stability.

\section{Data and Descriptive Statistics}

In the first instance, we report descriptive statistics for the selected variables. Data is averaged for the entire period (1970 to 2016) for the selected variables country-wide in order to show the mean values of natural resources and economic growth for all countries. The motivation behind this exercise is to understand the dependence of these countries on the export of their natural resources on average during the study period. Statistics are provided in the following Table 1.

The statistics reported in Table 1 demonstrate that in terms of total natural resource rents, Oman and Saudi Arabia dominate the Gulf region. The World Bank defines natural resources rents as "Total natural resources rents are the sum of oil rents, natural gas rents, coal rents (hard and soft), mineral rents, and forest rents. Variable and their definitions are listed in Appendix A. The world bank computes resources rents as the difference between revenue and the cost of extraction". The share of total natural resources rents in GDP is 32.826 and 32.337 percent for Oman and Saudi Arabia, respectively. Saudi Arabia and Oman received the highest natural resources rents of 77.367 and 71.772 percent, respectively. Similarly, the UAE economy received relatively lower rents as compared to Oman and Saudi Arabia. 
Table 1. Descriptive Statistics.

\begin{tabular}{ccccccc}
\hline Country & \multicolumn{2}{c}{ UAE } & \multicolumn{2}{c}{ SAUDI ARABIA } & \multicolumn{2}{c}{ OMAN } \\
\hline Variable & RENTS & GDP & RENTS & GDP & RENTS & GDP \\
\hline Mean & 21.854 & -1.971 & 32.337 & 1.454 & 32.826 & 1.712 \\
Median & 20.790 & -2.263 & 29.368 & 0.849 & 34.675 & 1.502 \\
Std. Dev & 7.433 & 6.964 & 15.613 & 11.791 & 13.382 & 6.342 \\
Max & 51.339 & 13.138 & 77.367 & 52.211 & 71.772 & 18.777 \\
Mini & 9.043 & -19.646 & 0.151 & -25.619 & 0.207 & -17.504 \\
Skewness & 1.551 & -0.245 & 0.115 & 1.369 & -0.568 & 0.008 \\
Kurtosis & 7.344 & 3.060 & 3.832 & 9.023 & 4.912 & 4.262 \\
No. Obs & 47 & 47 & 47 & 47 & 47 & 47 \\
\hline
\end{tabular}

Note: Authors calculation from WDI data using Eviews-9.1.

The contribution of total rents in GDP is 21.854 percent for the economy of UAE. The economy of the UAE received the highest total rents of 51.339 percent during the study period. In terms of economic growth, again, Oman and Saudi Arabia have achieved average economic growth of 1.712 and 1.454 percent, respectively, during the study period. Saudi Arabia achieved the highest and lowest economic growth of 52.211 and -25.619 percent. Similarly, the economy of Oman experienced the highest economic growth of 18.777 and the lowest economic growth of -17.504 percent during the study period. Surprisingly, the economic growth of the UAE remained on the average negative from 1970 to 2016. Based on statistics reported in Table 1 , the economic growth of UAE on average was -1.971 percent with a standard deviation of 6.964. The minimum and maximum values of economic growth are observed to be 13.138 and -19.646 percent, respectively.

In the next step, we plotted natural resource rents for all three economies in Figure 4 below for the study period 1970 to 2016. The purpose of drawing a graph is to observe the behavior of natural resources for sampled countries over the years. It could be seen from the graph that there are considerable variations in natural resource rents, specifically during the 1990s. Similarly, since then, there are just the usual ups and downs in natural resource rents for all three countries.

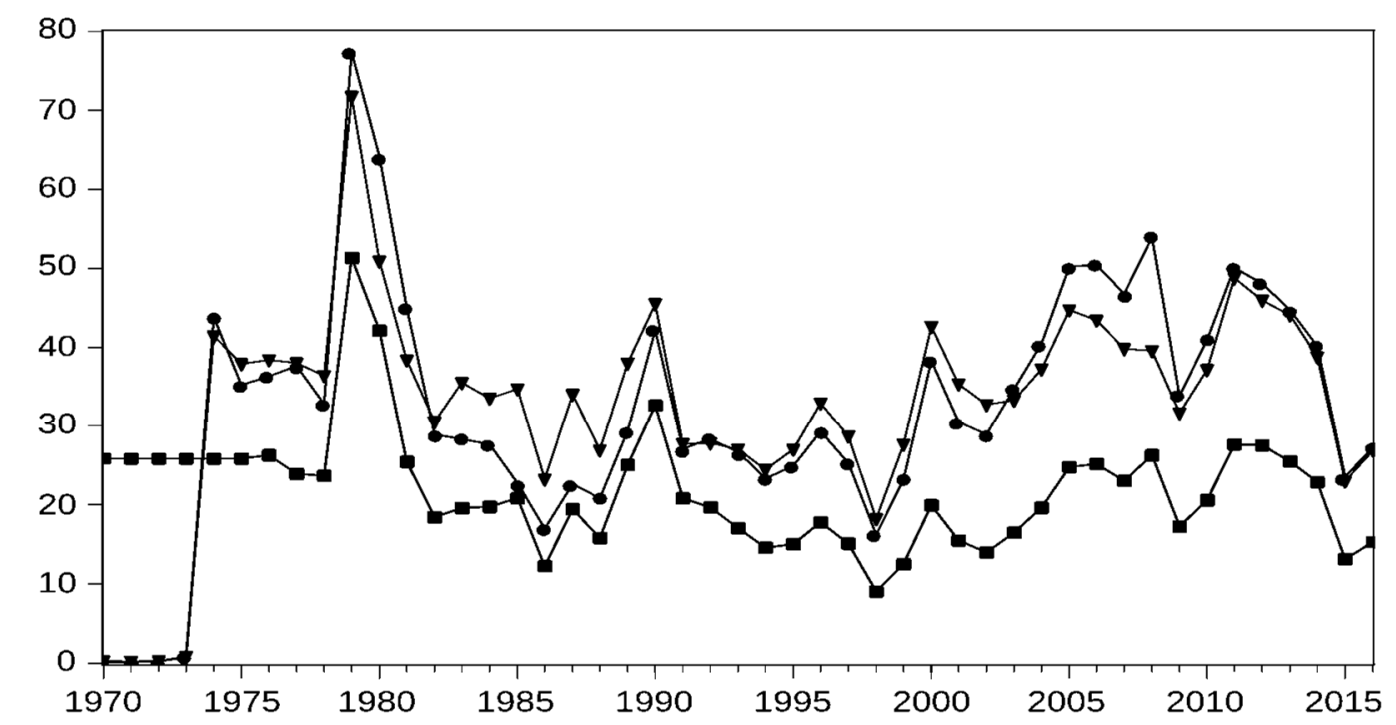

$\longrightarrow$ UAE Resources Rents $\multimap$ Saudi Resourcse Rents $\multimap$ Oman Resources Rents

Figure 4. Natural Resources Rents over time (1970-2016). Note: Figure 4 shows Natural resources rents received by UAE, Saudi Arabia, and Oman during the period 1970-2016. Natural resource rents are computed as a percentage of the GDP of the country. Data Source: World Bank databank. 


\section{Methodology}

Time series variables are mostly non-stationary by nature, and hence the techniques such as running the simple regression model would yield spurious inferences. Therefore, it is very important for a time series to be checked for stationarity properties. Therefore, for each time series, we constructed tests for both the levels and the first difference of the series. We applied both the augmented dicky fuller (ADF) by Dickey and Fuller (1979) and Philips Perron (PP) test by Phillips and Pierre (1988) to test for the stationarity of each series. For the ADF test, the lag length is automatically selected by the system based on minimum values of Schwartz information criteria (SIC), while for the PP, test the lag length is automatically selected according to Newey-West Bartlett Kernel. Both tests are conducted, including intercept only and intercept and trend.

\subsection{Conditional Volatility of Natural Resources Rents}

The volatility measure used in this paper is the conditional variance derived from the exponential generalized autoregressive conditional heteroscedasticity (EGARCH) model. The EGARCH model is an extended form of the GARCH model that efficiently captures the asymmetric effects and volatility clustering, as shown by Nelson (1991). The generic model for volatility is described below. Specific models appropriate for each time series are estimated.

$$
\begin{gathered}
\Delta \text { Rents }_{t}=\alpha+\beta \Delta \text { Rents }_{t-1}+\varepsilon_{t} \\
\log \left(\sigma_{t}^{2}\right)=\theta+\alpha\left(\frac{\left|\varepsilon_{t-1}\right|}{\sqrt{\sigma_{t-1}^{2}}}\right)+\beta\left(\frac{\varepsilon_{t-1}}{\sqrt{\sigma_{t-1}^{2}}}\right)+\gamma \log \left(\sigma_{t-1}^{2}\right)
\end{gathered}
$$

Equation (1) is the mean equation where $\Delta$ Rents $_{t}$ is the first difference of natural resources rents as a percentage of GDP and $\Delta$ Rents $_{t-1}$ is the one-year lagged value of the natural resources' rents. Whereas $\alpha$ and $\beta$ are coefficients to be estimated, and $\varepsilon_{t}$ is the idiosyncratic error term with standard white noise properties. Similarly, Equation (2) is the variance equation where the term $\varepsilon_{t-1}$ is the lagged value of the prediction error, the $\sigma_{t-1}^{2}$ is the lag of fitted variance from the mean Equation (1). The log transformation of the conditional variance ensures positive variance. Therefore, any further restrictions are not required in the GARCH model. In the Equation (2) above, $\theta, \alpha, \beta$, and $\gamma$ are the coefficients to be estimated where $\theta$ is the intercept, $\alpha$ shows the $\mathrm{ARCH}$ effect, which represents the impact of the conditional shock on conditional variance, $\beta$ shows the estimated leverage effect which indicates the symmetric effect of past errors. $\beta=0$ would indicate a symmetric shock effect while $\beta<0$ would show the presence of leverage effect. Lastly, $\gamma$ shows the estimated GARCH effect in the model.

\subsection{Effect of Conditional Volatility of Resources Rents on Economic Growth}

In this section, we describe the methods used for investigating the impact of natural resources rents and natural resource rents volatility on the economic growth of the country. Adopting the EGARCH framework from Nelson (1991), we used the log of conditional variance of the conditional mean equation to measure the conditional volatility of natural resources rents. The following model is estimated using the ordinary least squares (OLS) method

$$
G D P G_{t}=\alpha+\beta \Delta \text { Rents }_{t-1}+\gamma \Delta \log \left(\sigma_{t-1}^{2}\right)+\varepsilon_{t}
$$

where the dependent variable $G D P G_{t}$ is GDP growth per capita at time $t$ and the independent variables $\Delta$ Rents $_{t-1}$ is the one-year lagged value of natural resources rents, which is $\mathrm{I}(1)$, and $\Delta \log \left(\sigma_{t-1}^{2}\right)$ is the log of one year lagged conditional variance of natural resources rents that are obtained from the mean equation of the EGARCH (model 1 ) and $\varepsilon_{t}$ is the white noise error term with standard properties. The parameters to be estimated are $\alpha, \beta$, and $\gamma$. 


\subsection{Testing the Long-Run Relationship between Volatility of Resources Rents and Economic Growth (ARDL Approach)}

Testing for cointegration relationship in times series analysis has become essential. It shows the presence of a systematic co-movement among variables over a period. The presence of cointegration helps us to rule out the possibility of spurious regression. In this paper, we use the autoregressive distributed lag (ARDL) approach developed by Pesaran et al. (2001), to find the cointegrating relationship between GDP growth rate and natural resources rents. The model enables us to estimate the short-run and long-run effects of natural resource rents on economic growth. The reason behind using an ARDL bound test is that it can be applied to variables regardless of the degree of integration of those variables, especially in our case, where most GDP growth rate is $\mathrm{I}(0)$, and resources rents are $\mathrm{I}(1)$. The ARDL test can also be performed in our case as none of the variables in our study are $\mathrm{I}(2)$.

The ARDL method involves two stages. In the first stage, we test for a long-run relationship among variables. To test for that, we estimate the following model.

$$
\Delta G D P G_{t}=\beta_{0}+\sum \beta_{i} \Delta G D P G_{t-i}+\sum \gamma_{j} \Delta \log \sigma_{t-j}^{2}+\theta_{0} G D P G_{t-1}+\theta_{1} \log \sigma_{t-1}^{2}+\varepsilon_{t}
$$

Once the model is estimated, we perform the F-test for the following hypothesis

Hypothesis 1 (H1). $\theta_{0}=\theta_{1}=0$ indicating no long-term relationship against the alternative hypothesis of the presence of a long-term relationship between the variables.

Hypothesis 2 (H2). $\theta_{0} \neq \theta_{1} \neq 0$.

\subsection{Error Correction Model}

Once we establish the presence of a cointegrating relationship between the conditional volatility of natural resources' rents and the economic growth of the countries in question, we estimate the long-run equilibrium relationship between the variables with the following model.

$$
G D P G_{t}=\alpha_{0}+\alpha_{1} \log \sigma_{t}^{2}+v_{t}
$$

And the error correction model

$$
\Delta G D P G_{t}=\beta_{0}+\sum \beta_{i} \Delta G D P G_{t-i}+\sum \gamma_{j} \Delta \log \sigma_{t-j}^{2}+\varphi Z_{t-1}+\varepsilon_{t}
$$

where $Z_{t-1}=G D P G_{t-1}-\alpha_{0}-\alpha_{1} \log \sigma_{t-1}^{2}$ and the $\alpha_{0}$ and $\alpha_{1}$ are the OLS estimates from Equation (5).

We used Schwarz-Bayesian criterion (SBC) for the selection of lags, and we used the cumulative sum of recursive residuals (CUSUM) and the cumulative sum of squares of the recursive residuals (CUSUM) tests to test for the stability of the model.

\section{Results and Discussion}

\subsection{Unit Root and Stationarity}

In the first instance, we conducted unit root testing to identify the order of integration of variables. Both the ADF and PP test were employed, and results are provided in Table 2.

The results of unit root testing have confirmed that there is no variable having the order of integration greater than 1 which is required to carry out the further analysis. According to the results, all variables for all three countries are either stationary at level or at first difference.

\subsection{Conditional Volatility of Natural Resources Rents}

The conditional mean and conditional volatility Equations (1) and (2) of natural resources are estimated using EGARCH model to capture volatility clustering. The estimation results are presented in Table 3, which shows a positive and significant constant term for 
the mean equation in the case of each country. This indicates an increasing trend over time in the natural resources' receipts by each of the countries over the period 1970-2016.

Table 2. Unit root tests.

\begin{tabular}{|c|c|c|c|c|c|c|c|}
\hline \multirow{3}{*}{ Country } & \multirow{3}{*}{ Variable } & \multicolumn{2}{|c|}{ ADF } & \multicolumn{2}{|c|}{$\mathbf{P P}$} & \multirow{2}{*}{\multicolumn{2}{|c|}{$\begin{array}{c}\text { ADF PP } \\
\text { 1st Difference }\end{array}$}} \\
\hline & & \multicolumn{4}{|c|}{ Level } & & \\
\hline & & Intercept & $\begin{array}{l}\text { Intercept } \\
\text { and Trend }\end{array}$ & Intercept & $\begin{array}{l}\text { Intercept } \\
\text { and Trend }\end{array}$ & $\begin{array}{l}\text { Intercept } \\
\text { and Trend }\end{array}$ & $\begin{array}{l}\text { Intercept } \\
\text { and Trend }\end{array}$ \\
\hline UAE & $\begin{array}{l}\text { GDP Growth } \\
\text { Rents }\end{array}$ & $\begin{array}{l}-4.672 * * * \\
-3.333 * *\end{array}$ & $\begin{array}{l}-4.619^{* * *} \\
-3.562^{* *}\end{array}$ & $\begin{array}{l}-4.672^{* * *} \\
-3.280^{* *}\end{array}$ & $\begin{array}{l}-4.619^{* * *} \\
-3.470^{*}\end{array}$ & $-5.603^{* * *}$ & $-15.035^{* * *}$ \\
\hline Saudi Arabia & $\begin{array}{c}\text { GDP Growth } \\
\text { Rents }\end{array}$ & $\begin{array}{l}-6.611^{* * *} \\
-3.345^{* *}\end{array}$ & $\begin{array}{l}-6.374^{* * *} \\
-3.216^{*}\end{array}$ & $\begin{array}{l}-6.748^{* * *} \\
-3.210^{* *}\end{array}$ & $\begin{array}{c}-6.496^{* * *} \\
-3.113\end{array}$ & $-5.773^{* * *}$ & $-7.868^{* * *}$ \\
\hline Oman & $\begin{array}{l}\text { GDP Growth } \\
\text { Rents }\end{array}$ & $\begin{array}{l}-5.526^{* * *} \\
-3.715^{* * *}\end{array}$ & $\begin{array}{l}-5.648^{* * *} \\
-3.517^{* *}\end{array}$ & $\begin{array}{l}-5.453^{* * *} \\
-3.534^{* *}\end{array}$ & $\begin{array}{l}-9.099 * * * \\
-3.188 *\end{array}$ & $-5.009^{* * *}$ & $-9.016^{* * *}$ \\
\hline
\end{tabular}

Note: GDP Growth is the per capita real GDP growth rate and Rents is the natural resources rents computed as a percentage of GDP of the country. ADF is Augmented dicky fuller test, and PP is Philips Perron test both conducted with intercept, and intercept and trend. $*$ indicate significance at $10 \%$ level, ${ }^{* *}$ indicate significance at $5 \%$ level, and ${ }^{* *}$ indicate significance at $1 \%$ level.

Table 3. Results of Conditional Volatility of Natural resources rents derived from EGARCH model.

\begin{tabular}{cccc}
\hline & Saudi Arabia & UAE & Oman \\
\hline Mean Equation & ARMA (2,1) & AR (1) & AR (1) \\
$\alpha$ & $31.953^{* * *}$ & $18.392^{* * *}$ & $35.115^{* * *}$ \\
$\beta$ & $(4.517)$ & $(0.208)$ & $(2.092)$ \\
$\beta_{2}$ & $0.409^{* * *}$ & $0.554^{* * *}$ & $0.447^{* * *}$ \\
& $(0.130)$ & $(0.038)$ & $(0.069)$ \\
\hline Variance Equation & $0.776^{* * *}$ & & \\
$\varphi$ & $(0.082)$ & & $1.667^{* *}$ \\
$\alpha$ (ARCH) & $2.982^{* *}$ & $2.816^{* * *}$ & $(0.773)$ \\
$\beta$ (Leverage) & $(1.230)$ & $(0.000)$ & $-0.572^{* *}$ \\
$\gamma($ GARCH) & $-0.679^{* *}$ & $-1.713^{* * *}$ & $-0.418^{* *}$ \\
& $(0.301)$ & $(0.000)$ & $(0.171)$ \\
Diagnostics & -0.138 & $0.667^{* * *}$ & $(0.000)$ \\
Adjusted R-squared & $(0.222)$ & $0.512^{* * *}$ & $(0.172)$ \\
Durbin-Watson & $0.453^{* * * *}$ & $(0.000)$ & 0.367 \\
\hline
\end{tabular}

Note: The most appropriate model is estimated for each series based on the SC criteria. Standard errors are presented in parenthesis. Standard errors are given in parenthesis. ${ }^{* *},{ }^{* *}$ and ${ }^{*}$ denote rejection of the null hypothesis at the $1 \%, 5 \%$, and $10 \%$ level, respectively.

The coefficient of one year lagged natural resources (NR) is positive and significant for each of the country which indicates that current natural resources rents are influenced by the recent past natural resource rents. The ARCH term is negative and statistically significant for each of the three countries, which suggests that the conditional natural resources rents shock/innovation in each of the countries negatively affects the conditional volatility.

This implies that a greater than expected resource rents inflow has a lower effect than a greater than expected rents inflow on the conditional volatility of resource rents in each country. However, in the case of Saudi Arabia, the leverage effect is insignificant, which shows a symmetric effect of shock on conditional volatility of natural resources and the absence of leverage effect. On the other hand, the leverage effect is statistically significant for the UAE and Oman, indicating an asymmetric effect of shock on conditional volatility of natural resources. 
The coefficient of asymmetric shock is negative and insignificant for Saudi Arabia, negative and significant for Oman, and positive and significant in the case of UAE, which indicates an asymmetric effect of the conditional shock of natural resources both in the UAE and Oman on the conditional volatility of natural resources rents. More specifically, for instance, for the $\mathrm{UAE}$, a one-unit increase in the natural resource rents in the preceding year causes conditional volatility to decrease by $1.05(-1.71+0.66)$, while a one-unit decrease in shock is going to cause the conditional volatility to decrease by $2.43(-1.71-0.66)$.

The coefficient of GARCH estimates is positive and statistically significant both for the UAE and Oman, while it is insignificant at 5\% in the case of Saudi Arabia. The GARCH estimate is smaller in the case of UAE than in the case of Oman, indicating a quicker convergence to zero in the case of UAE compared to Oman.

In order to test for the stability of the autoregressive process, we used both CUSUM and CUSUMSQ tests. We can see that in each case, the CUSUM test indicates a stable process. However, the CUSUMSQ test shows signs of instability in the case of Saudi Arabia and the UAE. This contradiction in results is caused by the fact that we used the break in the intercept of the regression equation instead of the slope coefficient. In this case, the CUSUM test has higher power compared to the CUSUMSQ test (Turner 2010).

\subsection{Effect of Conditional Volatility of Resources Rents on Economic Growth}

The impact of conditional volatility of national resources on the economic growth of the three countries is estimated based on Equation (3) using OLS. The estimated results are presented in Table 4. The tables present the results based on two different models. The first model (I) is without $\Delta \mathrm{NR}_{\mathrm{t}-1}$, and the second model (II) is with $\Delta \mathrm{NR}_{\mathrm{t}-1}$ as an independent variable for each of the three economies.

Table 4. OLS Regression Estimates: Dependent variable: GDP Growth rate per capita.

\begin{tabular}{|c|c|c|c|c|c|c|}
\hline \multirow{2}{*}{$\begin{array}{c}\text { Country } \\
\text { Mean Equation }\end{array}$} & \multicolumn{2}{|c|}{ UAE } & \multicolumn{2}{|c|}{ Saudi Arabia } & \multicolumn{2}{|c|}{ Oman } \\
\hline & (I) & (II) & (I) & (II) & (I) & (II) \\
\hline Constant & $\begin{array}{l}-1.901 \\
(1.091)\end{array}$ & $\begin{array}{l}-1.8558 \\
(1.0189)\end{array}$ & $\begin{array}{l}-0.803 \\
(1.229)\end{array}$ & $\begin{array}{l}-0.667 \\
(1.177)\end{array}$ & $\begin{array}{l}1.379 * \\
(0.769)\end{array}$ & $\begin{array}{l}1.715 * * \\
(0.843)\end{array}$ \\
\hline$\Delta$ Rents $_{\mathrm{t}-1}$ & & $\begin{array}{c}0.3391 * * \\
(0.1435)\end{array}$ & & $\begin{array}{c}0.230^{* *} \\
(0.106)\end{array}$ & & $\begin{array}{c}0.118 \\
(0.075)\end{array}$ \\
\hline$\Delta \log \left(\sigma_{t-1}^{2}\right)$ & $\begin{array}{c}-1.346 \text { * } \\
(0.728)\end{array}$ & $\begin{array}{c}-1.0839 * * \\
(0.7102)\end{array}$ & $\begin{array}{c}-0.514^{* *} \\
(0.284)\end{array}$ & $\begin{array}{c}-0.495^{* *} \\
(0.268)\end{array}$ & $\begin{array}{c}-2.040^{* *} \\
(0.978)\end{array}$ & $\begin{array}{c}-2.460^{* *} \\
(1.110)\end{array}$ \\
\hline Diagnostics & & & & & & \\
\hline Adjusted R squared & 0.07 & 0.124 & 0.05 & 0.122 & 0.077 & 0.092 \\
\hline Durbin Watson & 1.358 & 1.79 & 1.70 & 1.70 & 1.10 & 0.93 \\
\hline
\end{tabular}

Note: The values in parenthesis are the standard errors. Annual real GDP growth per capita in percentage is the dependent variable. $\Delta N R_{t-1}$ is the first difference of the lagged natural resources rents and $\Delta \log \left(\sigma_{t-1}^{2}\right)$ is the first difference of the lagged conditional volatility of the natural resources' rents. Conditional volatility is the conditional variance derived from exponential GARCH model of natural resources rents regressed on one-year lagged natural resources rents and constant. The Durbin-Watson statistics > adjusted R2 exclude the possibility of spurious regression.

The results show that the effect of the first difference of natural resources rents is positive and significant in the case of Saudi Arabia and the United Arab Emirates. The effect of natural resource rents on economic growth in Oman is positive but insignificant. These results contradict the concept of Dutch disease. The findings could be justified as these countries have very large natural resource sectors, and the fraction of manufacturing exports is rather small, which might be the reason for not finding Dutch disease.

The effect of lagged conditional volatility is strongly negative and statistically significant for all the countries included in the study. This indicates that while this study rejects the presence of Dutch disease in the traditional way in these countries, the study does find a negative effect of the natural resource rents conditional volatility (innovation) on the economic growth of these countries.

The findings thus suggest that while the level of natural resources rent in these resource rich countries (except in the case of Oman) positively affects economic growth 
in these countries, the volatility or innovation of natural resources has a strong negative and significant effect on the economic growth of these countries. These results are very significant in the sense that they reject the traditional concept of natural resources curse as the natural resources were found to be positively affecting economic growth in these countries. However, the study found that the volatility of natural resources has a strong and statistically significant negative impact on the economic growth of all three countries.

The model fitness and stability of the estimated model is evaluated with the standard diagnostics. The values of adjusted R-squared and Durbin-Watson (DW) are reported in the table. The DW value is greater than the adjusted R-squared in each model, which indicate that the model is not spurious.

The results for ARDL bounds test of cointegration based on model (4) are reported in Table 5. The table presents the F-statistics value and critical values at $5 \%$ significance. The critical values reported are based on Pesaran and Yongcheol (1998), Pesaran et al. (2001), and Narayan (2005). The I(0) critical values assume the ARDL model to be $\mathrm{I}(0)$ and the I(1) critical values assume the ARDL model to be I(1).

Table 5. ARDL Bound Cointegration test.

\begin{tabular}{|c|c|c|c|c|c|c|c|}
\hline \multirow[t]{2}{*}{ Country } & \multirow[t]{2}{*}{ F-Statistics } & \multirow{2}{*}{$\begin{array}{c}\text { F Statistics } \\
\text { Without time trend }\end{array}$} & \multicolumn{2}{|c|}{ Critical Value at $5 \%$} & \multirow{2}{*}{$\begin{array}{c}\text { F Statistics } \\
\text { With time trend }\end{array}$} & \multicolumn{2}{|c|}{ Critical Value at $5 \%$} \\
\hline & & & $\mathrm{I}(0)$ & I (1) & & $\mathrm{I}(0)$ & I (1) \\
\hline UAE & F_(GDP $\backslash$ Rents $)$ & $12.136^{* * *}$ & 4.94 & 5.73 & $7.98^{* * *}$ & 4.05 & 4.49 \\
\hline Saudi Arabia & F_(GDP $\backslash$ Rents $)$ & $20.214^{* * *}$ & 4.94 & 5.73 & $14.163^{* * *}$ & 4.68 & 5.15 \\
\hline Oman & F_(GDP $\backslash$ Rents $)$ & $14.938^{* * *}$ & 4.94 & 5.73 & $10.446^{* * *}$ & 4.68 & 5.15 \\
\hline
\end{tabular}

Note: ${ }^{* * *},{ }^{* *}$ and ${ }^{*}$ denote rejection of the null hypothesis at the $1 \%, 5 \%$, and $10 \%$ level, respectively.

F_(GDP/Rents)-The F-statistics value are calculated based on the equation with real GDP growth rate per capita as a dependent variable and the conditional volatility of natural resources rents as independent variable.

We can see from the table that the F statistics values is bigger than the critical values in each case, suggesting that the variables real GDP growth per capita and natural resource rent volatility are cointegrated in all three economies. In the next stage, we estimate the error correction model, and the results are reported in Table 6.

Table 6. Error correction model estimation results.

\begin{tabular}{cccc}
\hline Coefficients & UAE & Saudi Arabia & Oman \\
\hline$C$ & -0.210 & -0.774 & 0.446 \\
$\Delta G D P G_{t-1}$ & $(1.123)$ & $(1.268)$ & $(0.807)$ \\
$\Delta \log \left(\sigma_{t-1}^{2}\right)$ & 0.119 & -0.188 & $0.312^{*}$ \\
& $(0.171)$ & $(0.146)$ & $(0.177)$ \\
$\Delta G D P G_{t-2}$ & 0.002 & 0.0009 & -0.023 \\
$\Delta \log \left(\sigma_{t-2}^{2}\right)$ & $(0.032)$ & $(0.003)$ & $0.029)$ \\
& & & 0.027 \\
ECM & & & $0.149)$ \\
& & & 0.039 \\
Diagnostics & $-0.827 * * *$ & $-0.698^{* * *}$ & $-0.946^{* * *}$ \\
R-Squared & $(0.202)$ & $(0.183)$ & $(0.224)$ \\
Durbin Watson & 0.33 & & 0.45 \\
\end{tabular}

Note: The values in parenthesis are the standard errors. ${ }^{* * *},{ }^{* *}$ and ${ }^{*}$ denote rejection of the null hypothesis at the $1 \%, 5 \%$, and $10 \%$ level, respectively.

The error correction term shows the speed of convergence to the equilibrium and adjustment in the model. The coefficient of the ECM term suggests how quickly a variable restores to equilibrium after the shock. The error correction term is negative and strongly significant for all three economies indicating evidence of a stable long-term relationship as 
shown by Bannerjee et al. (1998). The ECM term is -0.946 for Oman which is the biggest (in absolute terms) in the three economies, indicating the fastest convergence to equilibrium after experiencing an exogenous shock in Oman followed by the UAE and Saudi Arabia.

Therefore, we conclude that natural resources rents have impacted the economic growth of both Saudi Arabia and United Arab Emirates positively, and further this relationship is different from zero significantly. These findings are in line with the natural resource blessing hypothesis where the abundance of natural resources helps economies to overcome the contending obstacles to economic growth. In a similar study for Australian regions, Fleming et al. (2015) found that while natural resources have been found to have negatively affected some parts of the country, the resources boom has largely been a blessing for most of the Australian regions. Our results confirm the findings for the three gulf countries.

The results regarding the positive impact on natural resources on economic growth for Saudi Arabia are also consistent with those of Alkhathlan (2013). However, our analysis for the Saudi economy is more in-depth as Alkhathlan (2013) only considered the production of oil. Likewise, Haouas and Almas (2014) focused on United Arab Emirates and found evidence in favor of a natural resources curse. However, our findings about the absence of natural resources curse hypothesis for the United Arab Emirates could be justified by the fact that it attracts significant tourists from around the world. In a recent study, Kurecic and Filip (2017) found that natural resources do not affect economic growth negatively in tourism-dependent economies. The results are consistent with the findings of Soto and Ilham (2012) who concluded that natural resources have played a significant role in the economic activity and development strategy over the years.

As far as the economy of Oman is concerned, the study finds that although natural resources have impacted economic growth positively, this relationship is not significant. This insignificant impact of natural resources on economic growth could be because policy makers of Oman have started the process of economic diversification recently. However, the process of economic diversification is not satisfactory, as noted by Al Musalami (2016) who concluded that some resource curse is still present in the economy of Oman. Therefore, the economy of Oman is suggested to speed up the process of economic diversification to grow in the long run and beat the resource curse hypothesis.

However, there are multiple studies that found evidence of a natural resources curve. Mahler (2010) found evidence of a natural resources curse in the case of Nigeria. The study found that the natural resources curse in Nigeria is channeled through ethnic division and violence. However, the countries in our study are culturally and ethnically very homogenous and politically stable.

Our results further conclude that while natural resources abundance tends to positively affect economic growth of the country, it is the natural resource volatility that has a negative effect on the economic growth of the country. Natural resource rents are quantified in the natural resources' rents inflow; therefore, volatility in exports amounts as well as price shocks of resources are expected to adversely affect the economic growth of the host country. In a survey of literature on the natural resources curse, Frankel (2012) observes that commodity price volatility is one possible cause of the famous "natural resources curse". Thus, our study, while rejecting the presence of the natural resources curse in the traditional sense in heavily resource dependent countries, does provide evidence for a natural resources curse caused by resource export volatility. This also means that such resources-rich countries are exposed to a greater degree to outside negative demand shocks. This is the reason external economic recessions have been proven to transmit to resource-rich countries a lot earlier. Albassam (2015) concluded that Saudi Arabia is over-dependence on the oil sector and thus vulnerable to oil price shocks. In order to relieve their economy of the external price shocks and rent volatility, the Saudi economy needs a real diversification plan. Therefore, in 2016, the Saudi government launched the ambitious Vision 2030, a reform plan aimed at bolstering private sector employment for young people by diversifying the economy away from oil and focusing on sectors such 
as tourism, manufacturing, and renewable energy (Alghamdi 2019). Similar efforts are underway in the United Arab Emirates, where impressive progress is seen breaking into the high-tech industry.

\section{Conclusions}

The prime objective of this paper was to revisit and investigate the natural resource curse for three resource-rich countries, including Saudi Arabia, UAE, and Oman, during the period 1970-2016.

The results obtained have revealed that, indeed, natural resources matter from the perspective of economic growth. According to the results, both Saudi Arabia and UAE, in terms of economic growth, have benefited significantly from their rich natural resources. On the other hand, the relationship between natural resources and economic growth, although positive for the economy of Oman, remained insignificant statistically. These findings appeared to be in contradiction with the concept of Dutch disease. This apparently could be because in all these three countries, a very large fraction of their exported goods consists of natural resources, and the manufacturing exports make up a very small fraction of total goods exports. Therefore, the potential for a reduction in manufacturing exports due to expansion in the natural resources sector would be rather limited. In this study, we could not find evidence for the natural resources curse in the conventional sense. However, the study found that the volatility of natural resources has a strong and statistically significant negative impact on the economic growth of all three countries.

\section{Policy Implications}

Based on this comprehensive analysis, the study suggests the following points for the policymakers to consider.

(1) The results indicate that selected countries had escaped the resource curse problem. However, from the long-run growth perspective, efforts towards economic diversification should be the priority of all three countries. Economic diversification will help the selected countries in terms of growth performance, and hence the dependence on natural resources will be reduced significantly. Decreased dependence on natural resources will reduce their extraction, and hence the speed of environmental degradation will be slowed down, which is desirable.

(2) It is observed from the findings that the volatility of natural resources is harmful to economic growth. Natural resource rents are quantified in the natural resource rents inflow. Therefore, volatility in export amounts as well as price shocks of resources are expected to adversely affect the economic growth of the host country. Therefore, in order to avoid the negative shocks and resource rent volatility, these resource rich countries need to diversify their economy and focus specifically on human capital and intellectual capital accumulation and development.

Author Contributions: Conceptualization, A.H. and M.T.; methodology, A.H.; software, A.H.; validation, A.H. and M.T.; formal analysis, M.T.; investigation, A.H. and M.T.; resources, A.H.; data curation, A.H.; writing—original draft preparation, M.T.; writing—review and editing, M.T.; visualization, M.T.; supervision, M.T.; project administration, A.H.; funding acquisition, A.H. All authors have read and agreed to the published version of the manuscript."

Funding: This paper is the result of Metropolitan University Prague research project no. 74-02 "Territorial Studies, Economics, International Relations" (2020) based on a grant from the Institutional Fund for the Long-term Strategic Development of Research Organizations.

Institutional Review Board Statement: Not applicable.

Informed Consent Statement: Not applicable.

Data Availability Statement: Not applicable.

Conflicts of Interest: The authors declare no conflict of interest. 


\section{Appendix A}

Table A1. Data Sources and Definition of Variables.

\begin{tabular}{ccc}
\hline Variables & Definition & Data Source \\
\hline Rents & Total natural resources rents (\% of GDP) & World Development Indicators \\
GDPG & The growth rate of GDP per capita & World Development Indicators \\
\hline
\end{tabular}

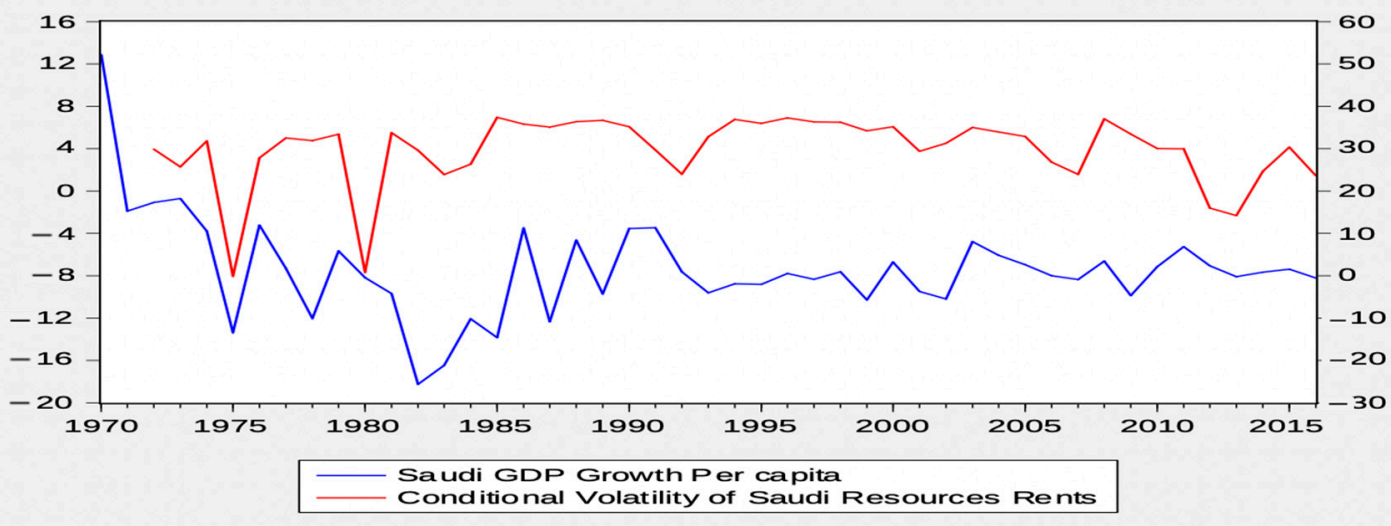

Figure A1. Conditional volatility of Saudi Arabia.

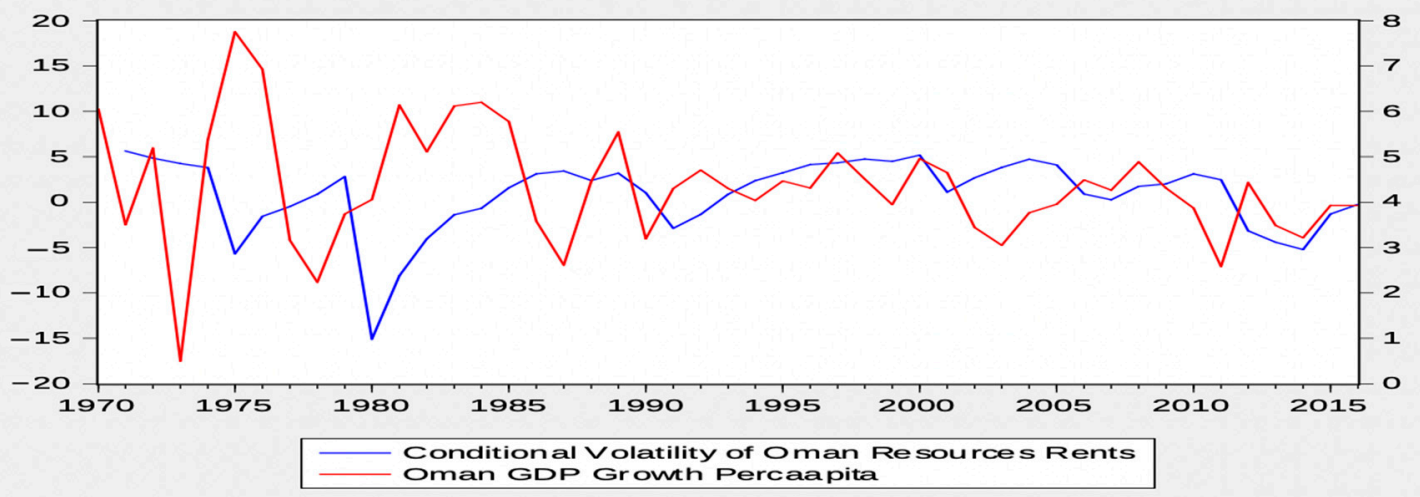

Figure A2. Conditional volatility of Oman.

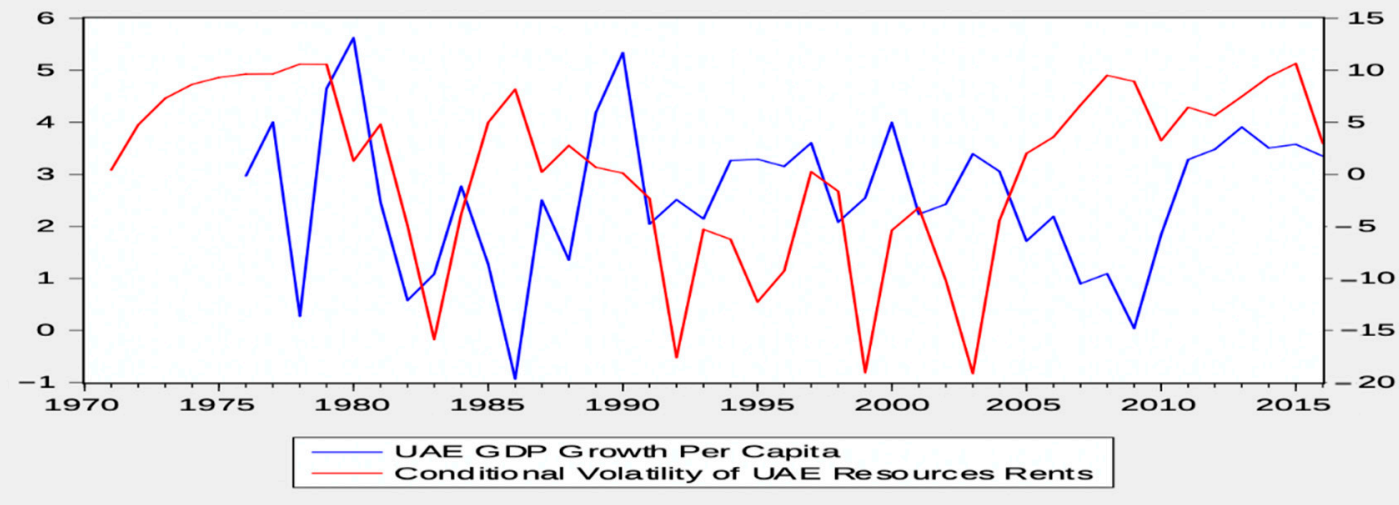

Figure A3. Conditional volatility of UAE. 


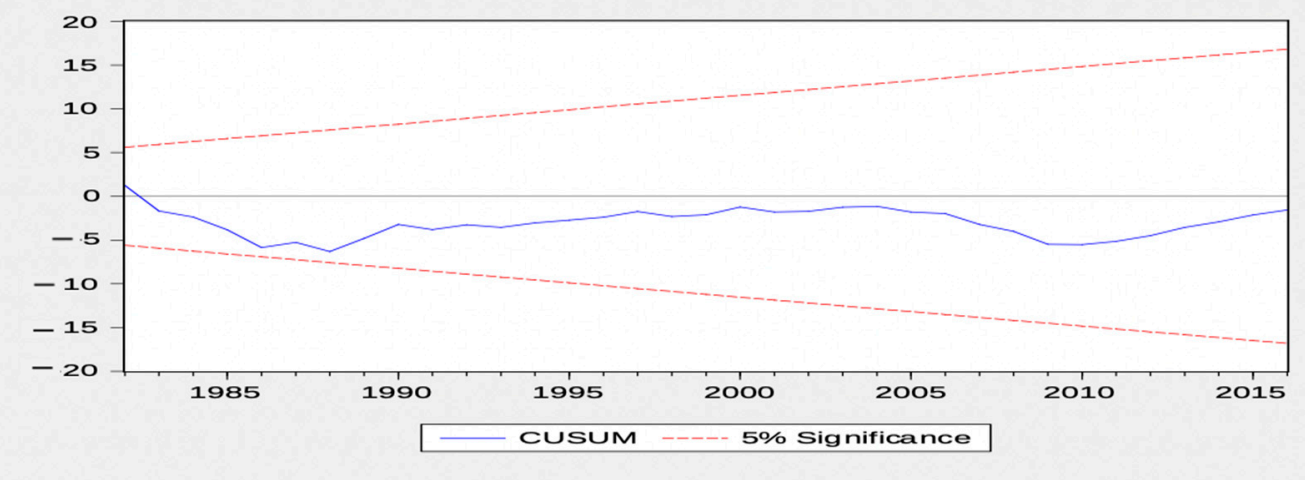

Figure A4. CUSUM Test (UAE).

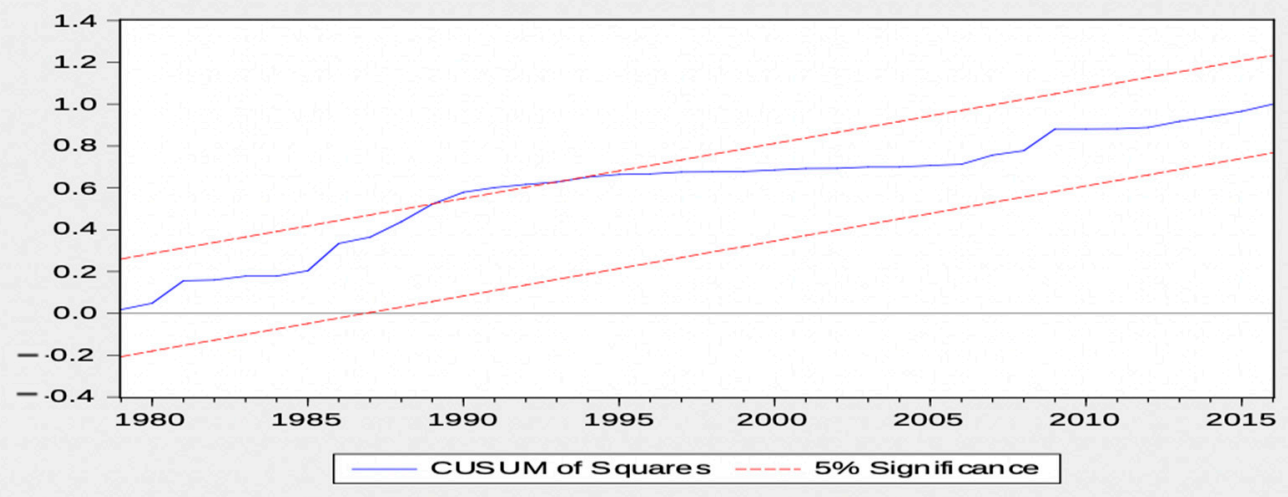

Figure A5. Square of CUSUM Test (UAE).

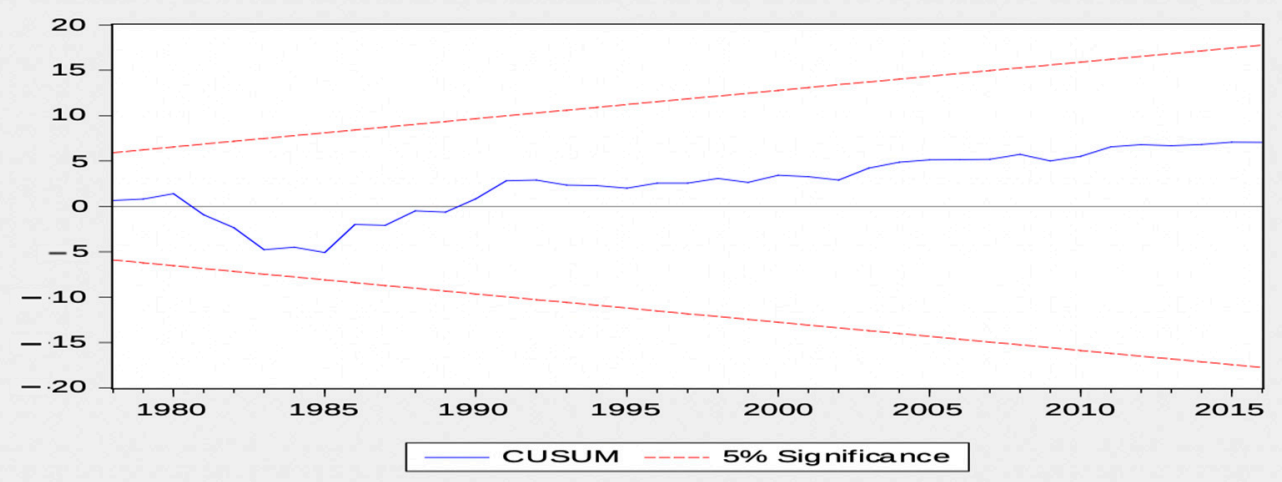

Figure A6. CUSUM Test (Saudi Arabia). 


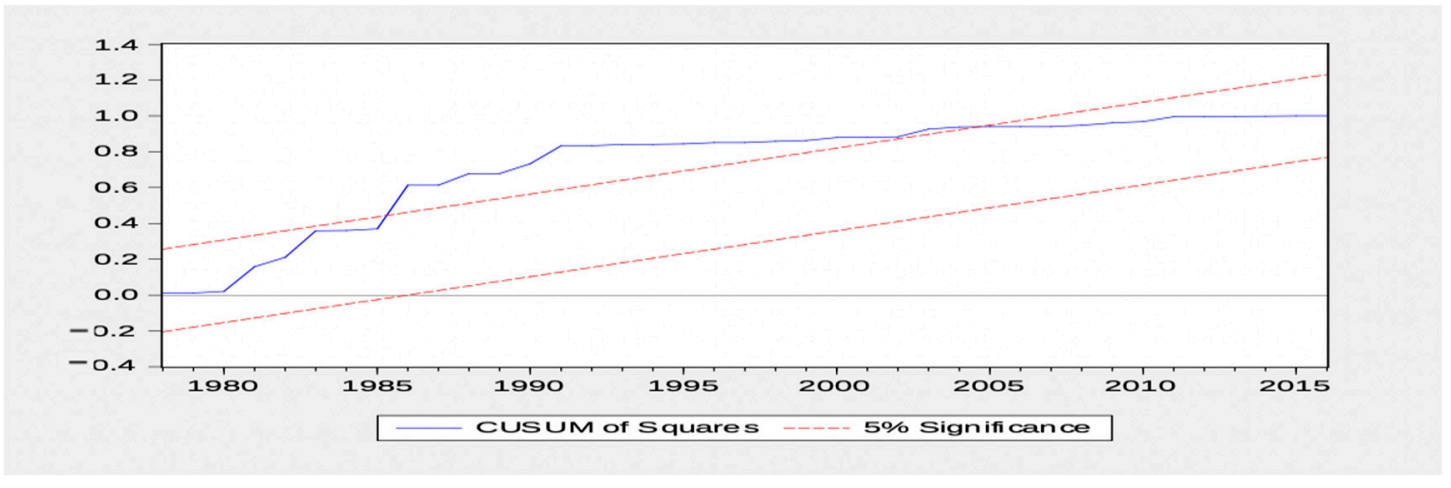

Figure A7. Square of CUSUM Test (Saudi Arabia).

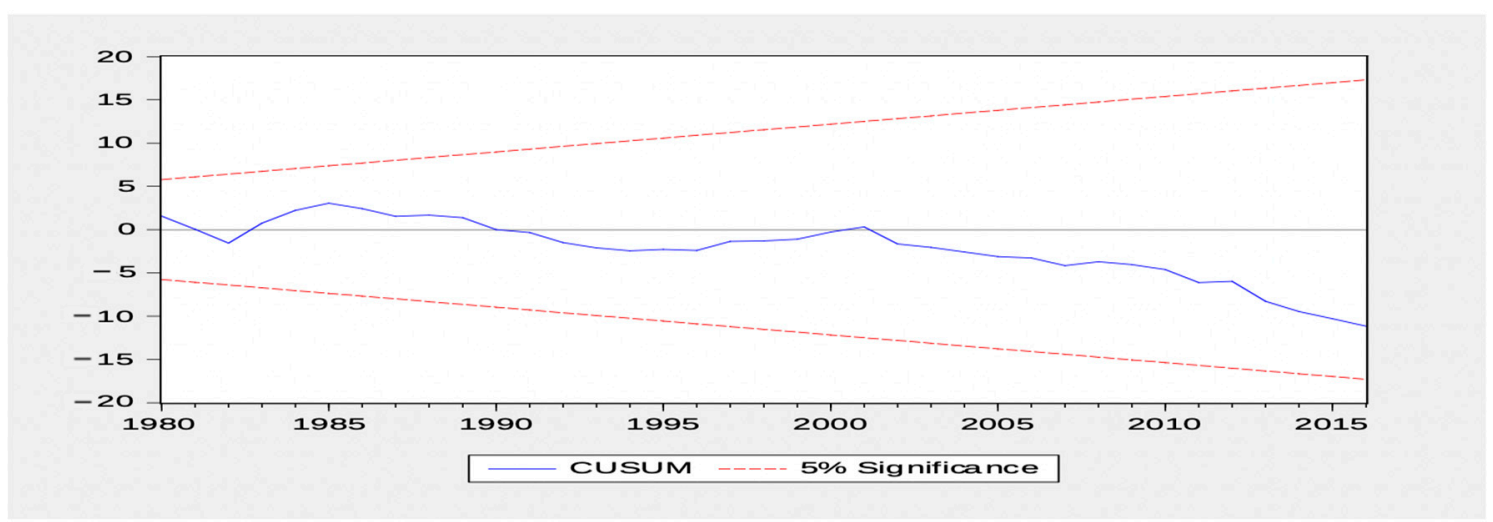

Figure A8. CUSUM Test (OMAN).

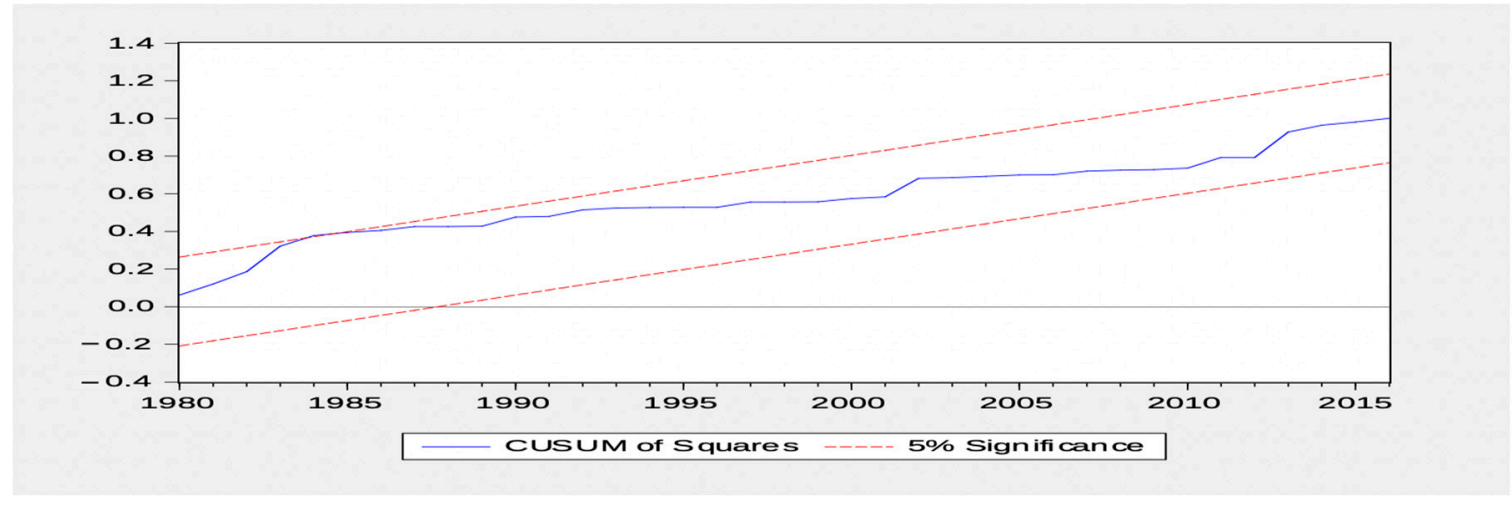

Figure A9. Square of CUSUM Test (OMAN).

\section{References}

Al Musalami, Juma S. 2016. Does Oman Surmount the Effects of the Resource Curse or Not? RSEP International Conferences on Social Issues and Economic Studies. Available online: http://rsepconferences.com/my_documents/my_files/6_JUMA_AL_ MUSALAMI.pdf (accessed on 25 September 2020).

Albassam, A. Bassam. 2015. Economic diversification in Saudi Arabia: Myth or reality? Resources Policy 44: 112-17. [CrossRef]

Alghamdi, Ahmed Saeed. 2019. A New Direction for the Saudi Arabian Economy. World Finance. Available online: https://www. worldfinance.com/featured/a-new-direction-for-the-saudi-arabian-economy (accessed on 25 September 2020).

Ali, Mohamed Sami Ben, Lara Cockx, and Nathalie Francken. 2016. The Middle East and North Africa: Cursed by Natural Resources? In Economic Development in the Middle East and North Africa. Edited by Mohamed Sami Ben Ali, Cockx Lara and Nathalie Francken. New York: Palgrave Macmillan.

Alkhathlan, Khalid A. 2013. Contribution of oil in economic growth of Saudi Arabia. Applied Economics Letters 20: 343-48. [CrossRef] Aoun, Marie-Claire. 2009. Oil and Gas Resources of the Middle East and North Africa: A Curse or a Blessing? The New Energy Crisis. Edited by Jean Marie Chevalier. London: Palgrave Macmillan. 
Arezki, Rabah, and Mustapha K. Nabli. 2012. Natural Resources, Volatility, and Inclusive Growth: Perspectives from the Middle East and North Africa, IMF Working Paper, WP/12/111. Available online: https://www.imf.org/external/pubs/ft/wp/2012/wp121 11.pdf (accessed on 25 September 2020).

Asiedu, Elizabeth. 2006. Foreign direct investment in Africa: The role of natural resources, market size, government policy, institutions and political instability. World Economy 29: 63-77. [CrossRef]

Asiedu, Elizabeth. 2014. Does foreign aid in education promote economic growth? Evidence from Sub-Saharan Africa. Journal of African Development 16: 37-59.

Asiedu, Elizabeth, and Donald Lien. 2011. Democracy, foreign direct investment and Natural Resources. Journal of International Economics 84: 99-111. [CrossRef]

Auty, Richard M. 1990. Resource-Based Industrialization: Sowing the Oil in Eight Developing Countries. New York: Oxford University Press.

Auty, M. Richard. 2004. Resource Abundance and Economic Development. Oxford Scholarship Online. Lancaster: Oxford Scholarship. [CrossRef]

Bannerjee, Anindya, Juan Dolado, and Ricardo Mestre. 1998. Error-correction Mechanism tests for Cointegration in a Single equation Framework. Journal of Time Series Analysis 19: 267-83. [CrossRef]

Birdsall, Nancy, and Subramanian Arvind. 2004. Saving Iraq from Its Oil. Foreign Affairs 83: 77-89. Available online: http: //www.jstor.org/stable/20034048 (accessed on 25 September 2020). [CrossRef]

Cavalcanti, Tiago. V. dev. V., Mohaddes Kamiar, and M. Raissi. 2011. Growth, development and natural resources: New evidence using a heterogeneous panel analysis. The Quarterly Review of Economics and Finance 51: 305-18. Available online: http: / / www.uq.edu.au/economics/abstract/406.pdf (accessed on 25 September 2020). [CrossRef]

Dickey, David A., and Wayne A. Fuller. 1979. Distribution of the estimators for autoregressive time series with a unit root. Journal of the American Statistical Association 74: 427-31.

Erum, Naila, and Hussain Shahzad. 2019. Corruption, natural resources, and economic growth: Evidence from OIC countries. Resources Policy 63: 101429. [CrossRef]

Fleming, A. David, G. Thomas Measham, and Paredes Dusan. 2015. Understanding the resource curse (or blessing) across national and regional scales: Theory, empirical challenges and an application. Agriculture and Resource Economics 59: 624-39. [CrossRef]

Frankel, A. Jeffrey. 2012. The Natural Resource Curse: A Survey of Diagnoses and Some Prescriptions. Available online: https://www. researchgate.net/publication254407482_The_Natural_Resource_Curse_A_Survey_of_Diagnoses_and_Some_Prescriptions (accessed on 23 July 2020).

Gelb, Alan. 1988. Oil Winfalls: Blessing or Curse? New York: Oxford University Press.

Gylfason, Thorvaldur. 2001. Nature, Power and Growth. Scottish Journal of Political Economy 48: 558-88. [CrossRef]

Gylfason, Thorvaldur, and Zoega Gylfi. 2006. Natural resources and economic growth: The role of investment. World Economy 29: 1091-115. [CrossRef]

Haouas, Ilham, and Heshmati Almas. 2014. Can the UAE Avoid the Oil Curse by Economic Diversification? IZA DP No. 8003. Available online: http:/ / ftp.iza.org/dp8003.pdf (accessed on 25 September 2020).

Ibhagui, Oyakhilome. 2020. How does foreign direct investment affect growth in sub-Saharan Africa? New evidence from threshold analysis. Journal of Economic Studies 47: 149-81. [CrossRef]

Iimi, Atsushi. 2007. Escaping from the Resource Curse: Evidence from Botswana and the Rest of the World. IMF Staff Papers 54: 663-99. [CrossRef]

Kurecic, Petar, and Kokotovic Filip. 2017. Examining the "Natural Resource Curse" and the Impact of Various Forms of Capital in Small Tourism and Natural Resource-Dependent Economies. Economies 5: 6. [CrossRef]

Mahler, Annegret. 2010. Nigeria: A Prime Example of the Resource Curse? Revisiting the Oil-Violence Link in the Niger Delta, GIGA Working Paper No. 120. Available online: https:/ /www.open.edu/openlearn/ocw/pluginfile.php/1410427/mod_resource/ content/1/ca_1_maehler.pdf (accessed on 25 September 2020).

Manzano, Osmel, and Roberto Rigobon. 2001. Natural Resource Curse or Debt Overhang? National Bureau of Economic Research, Working Paper No. 8390. Available online: https://www.nber.org/system/files/working_papers/w8390/w8390.pdf (accessed on 25 September 2020). [CrossRef]

Narayan, Paresh Kumar. 2005. The saving and investment nexus for China: Evidence from cointegration tests. Applied Economics 37: 1979-90. [CrossRef]

Nelson, B. Daniel. 1991. Conditional heteroskedasticity in asset returns: A new approach. Econometrica 59: 347-70. [CrossRef]

Paltseva, Elena, and Roine Jesper. 2011. Resource Curse: What Do We Know about It? Policy Brief Series. Available online: https:/ / freepolicybriefs.org/wp-content/uploads/2011/11/free_policy_brief_paltseva_roine.pdf (accessed on 6 July 2020).

Pesaran, H. Hashem, and Shin Yongcheol. 1998. Generalized impulse response analysis in linear multivariate models. Economics Letters 58: 17-29. [CrossRef]

Pesaran, H. Hashem, Shin Yongcheol, and Richard. J. Smith. 2001. Bounds testing approaches to the analysis of level relationships. Journal of Applied Econometrics 16: 289-326. [CrossRef]

Phillips, Peter, and Perron Pierre. 1988. Testing for a unit root in time-series regression. Biometrica 75: 335-46. [CrossRef]

Raggl, K. Anna. 2017. Natural Resources, Institutions, and Economic Growth: The Case of Nigeria. Policy Paper No. WPS 8153. Washington: The World Bank. 
Sachs, Jeffrey D., and Andrew M. Warner. 1995. Natural Resources Abundance and Economic Growth. National Bureau of Economic Research, Working Paper Series, Paper No. 5398. Available online: https://www.nber.org/system/files/working_papers/w539 8/w5398.pdf (accessed on 25 September 2020). [CrossRef]

Sachs, Jeffrey D., and Andrew M. Warner. 2001. The Curse of Natural Resources. Natural Resource and Economic Development 45: 827-38. [CrossRef]

Sala-i-Martin, Xavier, and Arvind Subramanian. 2003. Addressing the Natural Resource Curse: An Illustration from Nigeria. National Bureau of Economic Research, Working Paper Series, Paper No. 9804. Available online: https://www.nber.org/system/files/ working_papers/w9804/w9804.pdf (accessed on 25 September 2020). [CrossRef]

Soto, Raimundo, and Haouas Ilham. 2012. Has the UAE escaped the oil curse? The Economics Research Forum. Working Paper No. 728. Available online: https:/ / erf.org.eg/publications/uae-escaped-oil-curse/ (accessed on 25 September 2020).

Turner, P. 2010. Power properities of the CUSUM and CUSUMSQ tests for parameter instability. Applied Economics Letters 17: 1049-53. [CrossRef]

Zallé, Oumarou. 2019. Natural resources and economic growth in Africa: The role of institutional quality and human capital. Resources Policy 62: 616-24. [CrossRef] 